\title{
ATELLE
}

\section{O Carste e o Geopatrimônio em Júlio Verne: o exemplo de Mathias Sandorf}

\author{
The Karst and the Geoheritage in Jules Verne: the example \\ of Mathias Sandorf \\ Le Karst et le Geoheritage de Jules Verne: l'exemple de \\ Mathias Sandorf
}

Luiz Eduardo Panisset Travassos

Pontifícia Universidade Católica de Minas Gerais

luizepanisset@gmail.com

Glaycon de Souza Andrade e Silva

Pontifícia Universidade Católica de Minas Gerais

glaycongeografia@gmail.com

Felipe de Ávila Chaves Borges

Pontifícia Universidade Católica de Minas Gerais

felipeacborges@gmail.com

\begin{abstract}
Resumo
As cavernas e as paisagens nas quais estão inseridas têm povoado o imaginário coletivo de diversas culturas, seja por meio de lendas e mitos de criação, seja por fazerem parte do cenário de relatos de viagem ou romances. Assim sendo, a pesquisa tem por finalidade demonstrar de que forma o Carste Dinárico e a Pazinska Jama são retratados no livro Mathias Sandorf, de Júlio Verne. A análise foi desenvolvida de maneira associativa aos conceitos tanto da Carstologia, quanto da Espeleologia a fim de identificar no texto de Júlio Verne sua contribuição para demonstrar aos leitores aspectos da geografia física do carste. Para que o objetivo fosse atingido, os autores analisaram a narrativa do autor, bem como pesquisaram os aspectos da geomorfologia cárstica. Os resultados apontaram para a união entre ficção e realidade favorecendo, inclusive, pesquisas científicas após a publicação do livro.
\end{abstract}

Palavras-chave: Júlio Verne; Carste; Geopatrimônio.

\footnotetext{
Abstract

Caves and the landscapes in which they are present have populated the collective imaginary of diverse cultures, either through legends and myths of creation, or
} 
because they are part of the scenario of travel reports or novels. Thus, the research aims to demonstrate how the Dinaric Karst and the Pazinska Jama are portrayed in the book Mathias Sandorf, by Jules Verne. The analysis was developed in an associative way to the concepts of both Karstology and Speleology in order to identify in the text of Verne his contribution to demonstrate to the reader's aspects of the physical geography of karst. In order to reach the objective, the authors analyzed the narrative of the author as well as researched aspects of karst geomorphology. The results pointed to the union between fiction and reality even favoring scientific research after the publication of the book.

Keywords: Jules Verne; Karst; Geoheritage.

\begin{abstract}
Résumé
Les grottes et les paysages dans lesquels elles s'insèrent ont peuplé l'imaginaire collectif de diverses cultures, soit à travers les légendes et les mythes de la création, soit parce qu'elles font partie du scénario des récits de voyage ou des romans. Par conséquent, ce travail a pour but de montrer comment le karst dinarique et le Pazinska Jama sont représentés dans le livre 'Mathias Sandorf', de Jules Verne.L'analyse a été développée de manière associative aux concepts de karstologie et de spéléologie afin d'identifier dans le texte de Jules Verne sa contribution à démontrer aux lecteurs des aspects de la géographie physique du karst. Afin d'atteindre cet objectif, les auteurs ont analysé le récit de Verne et ont également étudié des aspects de la géomorphologie karstique. Les résultats ont mis en évidence l'union entre la fiction et la réalité, favorisant même la recherche scientifique après la publication du livre.

Mots-clés: Jules Verne; Karst; Geoheritage.
\end{abstract}

\title{
Introdução
}

Dentro do campo da Geografia Física, mais precisamente da Geomorfologia, há um campo de pesquisa que trata do relevo desenvolvido em litologias mais solúveis como as rochas carbonáticas (e.g. calcários e dolomitos), por exemplo. Este relevo é denominado na literatura internacional como karst e, em português, carste. Sua gênese ocorre a partir da dissolução da rocha em contato com a água superficial ou subterrânea, gerando formas características na paisagem (e.g. dolinas, canais de dissolução - Karren -, cavernas, poljes, sumidouros, condutos de drenagem subterrânea etc.). $\mathrm{O}$ interesse por este tipo de paisagem e estrutura geológica fez com que diversos profissionais das Ciências da Terra se debruçassem em estudos mais aprofundados dando origem ao campo específico de estudos denominado Carstologia (TRAVASSOS, 2010; TRAVASSOS, 2014).

Em relação à paisagem cárstica, Piló e Auler (2011) afirmam que, como um sistema, o carste é composto pelo ambiente externo (exocarste), o ambiente interno (endocarste) e ainda uma zona de transição intermediária entre a superfície do solo e a rocha (epicarste).

No campo da Espeleologia, área do conhecimento que trata da geomorfologia subterrânea, as cavernas são locais que têm atraído preocupação conservacionista devido 
às suas características ambientais peculiares como a estabilidade climática, a ausência total de luz natural e sua biota específica.

As cavernas são ambientes que se originam por processos primários e secundários. Dessa forma, as cavernas primárias são aquelas formadas simultaneamente aos processos de formação das rochas, como os tubos de lava, por exemplo. Já as secundárias, são aquelas desenvolvidas após a formação da rocha. São, portanto, as mais comuns (AULER; PILÓ, 2011; TRAVASSOS, 2010; 2014).

Diante disso, este trabalho tem por finalidade demonstrar de que forma o Carste Dinárico (Figura 1) e a Pazinska Jama são retratados no livro Mathias Sandorf (VERNE, 1885/1965). A análise foi desenvolvida de maneira associativa aos conceitos tanto da Carstologia, quanto da Espeleologia a fim de identificar no texto de Júlio Verne, sua contribuição para demonstrar aos leitores os aspectos da geografia física do carste.

Para que o objetivo fosse atingido, os autores analisaram a narrativa de Júlio Verne, bem como pesquisaram os aspectos da geomorfologia cárstica da região da Ístria (Croácia), cenário escolhido pelo autor para seu livro.

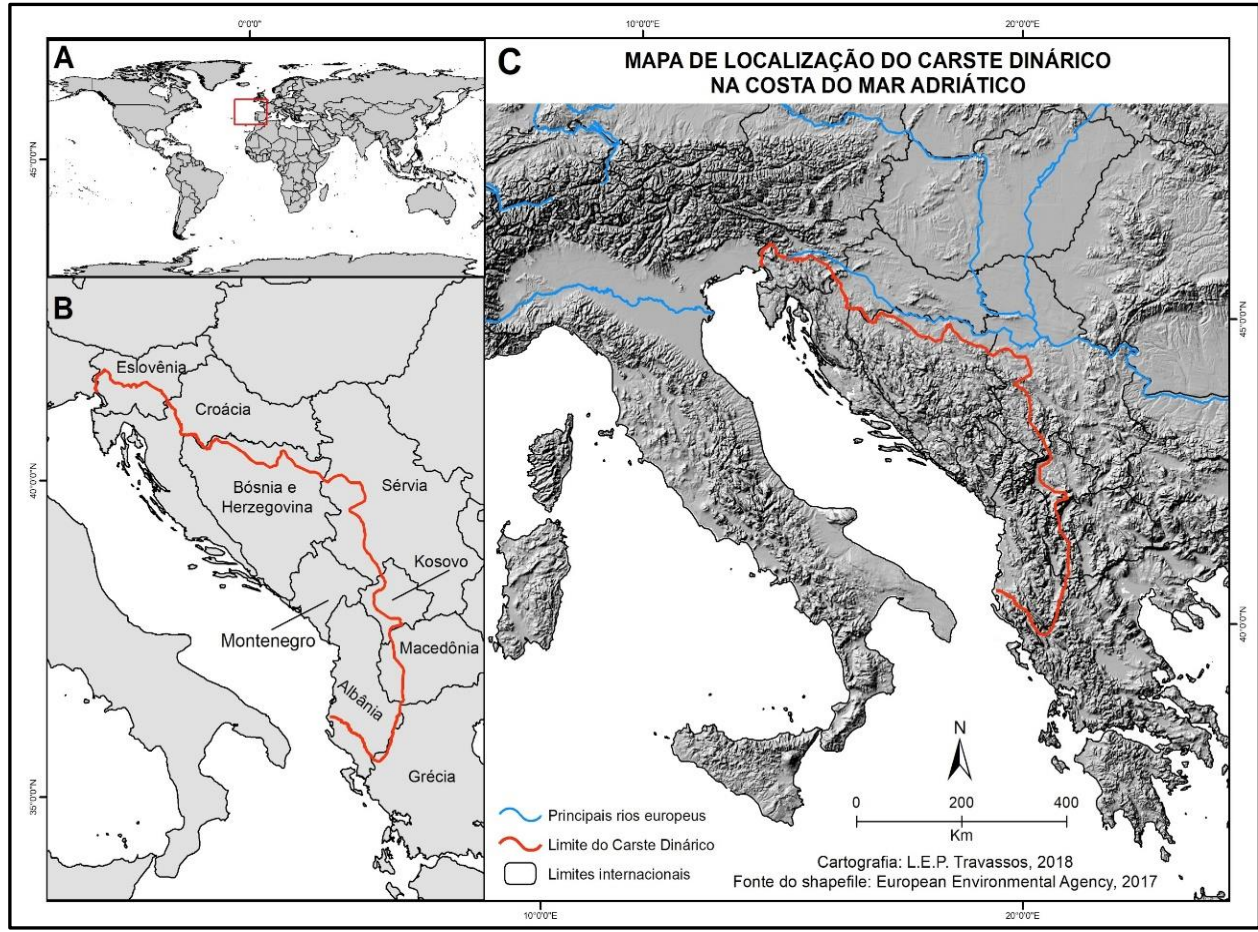

Figura 01. Mapa de localização do Carste Dinárico que é retratado no livro Mathias Sandorf. 


\section{Geografia, Literatura e Literatura de Viagens}

As obras que focam a geografia, a literatura e a literatura de viagens são ricas contribuições para a construção histórica de determinado grupo social ou comunidade, pois transmitem experiências de lugares inóspitos, singulares e até aqueles recém descobertos, mesmo que Cene e Ferraz (2016) afirmem que literatura e ciência sejam narrativas ou visões de mundo diferentes quanto ao uso da linguagem e os conceitos.

Desde a Antiguidade muitos viajantes compilavam histórias de diversas formas com o intuito de repassa-las às futuras gerações. Assim, de acordo com Amorim Filho (2008), os textos podem ser classificados como narrativas orais, relatos escritos, diários, croquis e desenhos, por exemplo. Ainda para o autor, a literatura de viagens pode ser dividida em dois grandes grupos, a saber: 1) um conjunto numeroso de obras em que o romanesco é o foco central, ainda que se utilize das descrições geográficas de regiões, lugares e paisagens como cenários indispensáveis para seus enredos e, 2) um outro conjunto de trabalhos para os quais os itinerários, regiões, lugares e paisagens são os próprios objetivos, caracterizando-se como estudos mais científicos e geográficos (AMORIM FILHO, 2008, p.109).

Em relação aos livros de Júlio Verne, é possível observar que apresentam aspectos imaginários, culturais, romancistas e científicos nos quais as narrativas tratam de personagens fictícios e não fictícios que fazem conexões com o mundo real e situações cotidianas. Dessa forma, acredita-se que Verne se encaixa no grupo 1, ou seja, o romanesco é o foco central, embora as descrições geográficas de regiões, lugares e paisagens sejam cenários indispensáveis para seus enredos.

A literatura de viagens possui um caráter interdisciplinar, pois descrevem paisagens, culturas e contextos sociais tornando-se um gênero literário que propicia uma excepcional fonte documental. Ressalta-se aqui, as contribuições dadas por Alexandre von Humboldt e Carl Ritter. Conforme Augustin (2006, p.11), o texto resultante é tanto pensamento quanto poesia, o que, para Kant, são quase sinônimos.

Em muitos casos percebe-se que não é possível separar um relato da viagem em si, pois a viagem fornece as condições de produção, ainda que a viagem e o relato possam ter sido realizados por pessoas diferentes. Dessa forma, é preciso identificar quais as motivações existem para realização da viagem, bem com qual seria sua finalidade além do cenário mundial em que ocorrem. Por isso, ainda é preciso diferenciar um relato de viagem da literatura de viagens propriamente dita (SCHEMES, 2015).

Com a exceção dos livros que fundaram as grandes rotas de viagens, os relatos de viagem são formados tanto pela experiência real do viajante como pela escrita de viajantes anteriores, mesclando frases como "eu vi" ou "eu li", fato que muitas vezes torna difícil para o leitor separar o que foi presenciado do que foi lido. Isso ocorre ou porque estas foram tomadas com "orientação" prática para o novo viajante ou porque a memória deste último não consegue apagar os traços deixados pelos textos lidos antes da escrita de 
sua autoria (TOBAR, 2005 apud CUNHA, 2012, p.157). Por esse motivo, Cunha (2015) destaca a que a literatura de viagens é um gênero de fronteira que agrega diversas tipologias textuais e que dificultam a separação entre ficção e realidade.

Nesta perspectiva, ao produzir o texto de Mathias Sandorf, Júlio Verne buscou referência nas obras Trieste e I'Istria (1875) e Les Bords de L'Adriatique et Le Monténégro (1878) de Charles Yriarte. Nestes livros, Yriarte descreveu minuciosamente a Península na costa do Adriático, registrando desde aspectos físicos-naturais a urbanos-culturais. Destaca-se, ainda, que Verne viajou com sua família em um cruzeiro pelo Mediterrâneo, visitando Tânger e Malta. Outra referência de Verne para escrever o livro foi o contato junto ao prefeito de Pazin, Giuseppe Cech, que lhe forneceu detalhes sobre a cidade e imagens do castelo, da Foiba e partes antigas da cidade (ŠIŠOVIC, 2003). Na Carstologia e na Espeleologia, vale a pena lembrar que uma das formais mais características da paisagem são as depressões fechadas ou grandes gargantas. Em Mathias Sandorf, tem-se a Foiba, nome regional para designar uma grande dolina de abatimento.

É importante destacar que Šišovic (2003) afirma que Charles Yriarte publicou um excelente desenho panorâmico de Pazin, com sua grande dolina e a Pazinska Jama ou Caverna de Pazin, em primeiro plano (Figura 2). Além de outras impressões sobre Pazin, Yriarte descreveu cuidadosamente a arquitetura do castelo e a visada que se teria da entrada da caverna abaixo dele. Yriarte (1878) chega até a mencionar um episódio onde um jovem funcionário da municipalidade entrou no lago da Caverna de Pazin com um pequeno barco, mas não conseguiu chegar ao final.

Dessa forma, o autor repetiu a ideia e a tradição oral da época que afirmava que o Rio Pazinčica fluiria quilômetros ao longo da caverna para somente ressurgir na costa oeste da Ístria. Não é por acaso que o herói criado por Verne tenha feito essa mesma trajetória, mesclando ficção e "realidade". Suas descrições foram tão perfeitas que inspiraram o famoso espeleólogo francês Édouard-Alfred Martel a visitar Pazin, em 1893, e mais duas vezes após esse ano. Os resultados de suas pesquisas foram publicados em 1894, 1896 e 1897. Juntamente com Wilhelm Putick, de Ljubljana, elaboraram o primeiro mapa da caverna que mostrava a impossibilidade da fuga de Sandorf, embora não tenha sido esse o objetivo principal do mapeamento (Figura 03). 

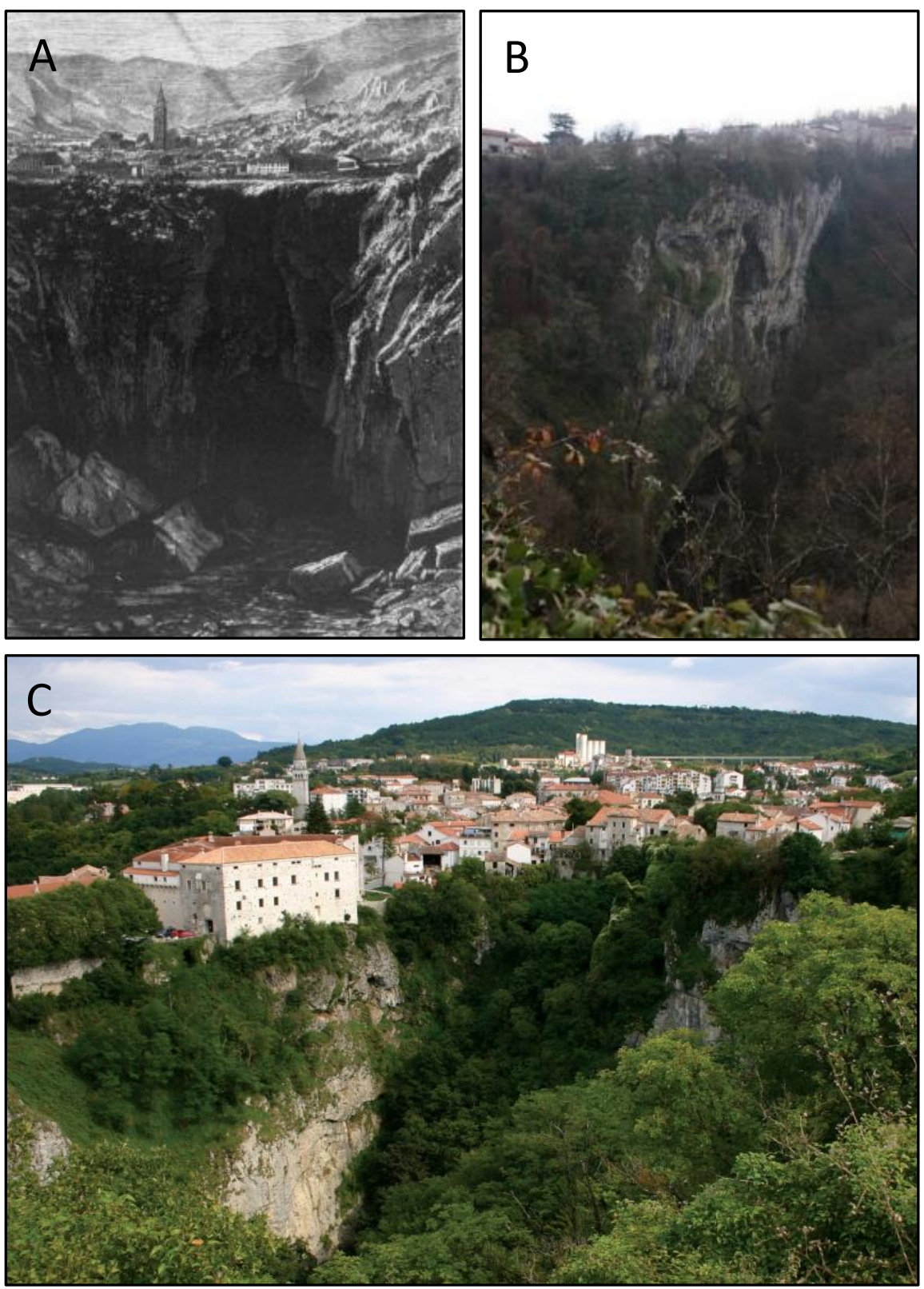

Figura 02. Em A, a vila de Pazin e a entrada da Caverna (YRIARTE, 1878, p.111) e em B, parte do maciço com a vila no topo (Foto: L.E.P. Travassos, 2011). Em C tem-se uma visão panorâmica fornecida pelo site do Castelo de Pazin, Croácia. 


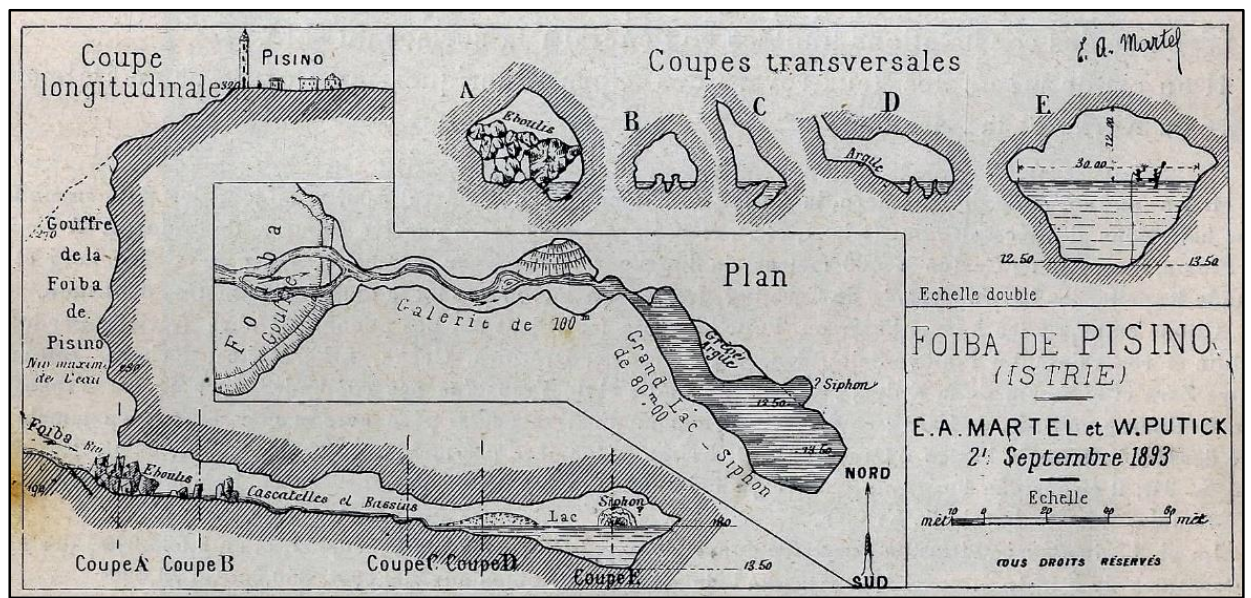

Figura 03. Mapa da Caverna de Pazin que foi produzido por Martel e Putick, em 1893. $\mathrm{Na}$ imagem é possível perceber cortes longitudinais e transversais, bem como a planta baixa da caverna

Fonte: MARTEL, 1894, p.479.

Além do imaginário coletivo em relação ao subterrâneo e ao carste de maneira geral, Kuhta (2011) destaca o fato da Caverna de Pazin apresentar o maior rio subterrâneo de toda a Ístria. Sua importância é confirmada pela inscrição da caverna e todo seu entorno no Registro Geomorfológico de Monumentos Naturais da Croácia, em 1964. Dessa forma, acredita-se que sua importância como geopatrimônio regional seja inegável (Figura 04).

Brilha (2018) afirma que o geopatrimônio ou patrimônio geológico são aqueles elementos específicos da geodiversidade de um local que são considerados merecedores de conservação devido sua importância e valor, sejam tais elementos encontrados in situ (geossítios) ou ex situ (elementos de geopatrimônio). Além disso, é aceitável que os museus de história natural e suas coleções possam fazer parte disso. $\mathrm{O}$ patrimônio geológico materializa-se na forma de minerais, fósseis, rochas, formas de relevo e suas paisagens, solos e processos geológicos e geomorfológicos ativos que possuam grande relevância científica (BRILHA, 2018), assim como exemplificado pela Caverna de Pazin e seu entorno. Além disso, nesse contexto considera-se tanto elementos atuais como aqueles mais antigos, expandindo a noção de patrimônio relacionada exclusivamente a heranças (GRAY, 2018). 


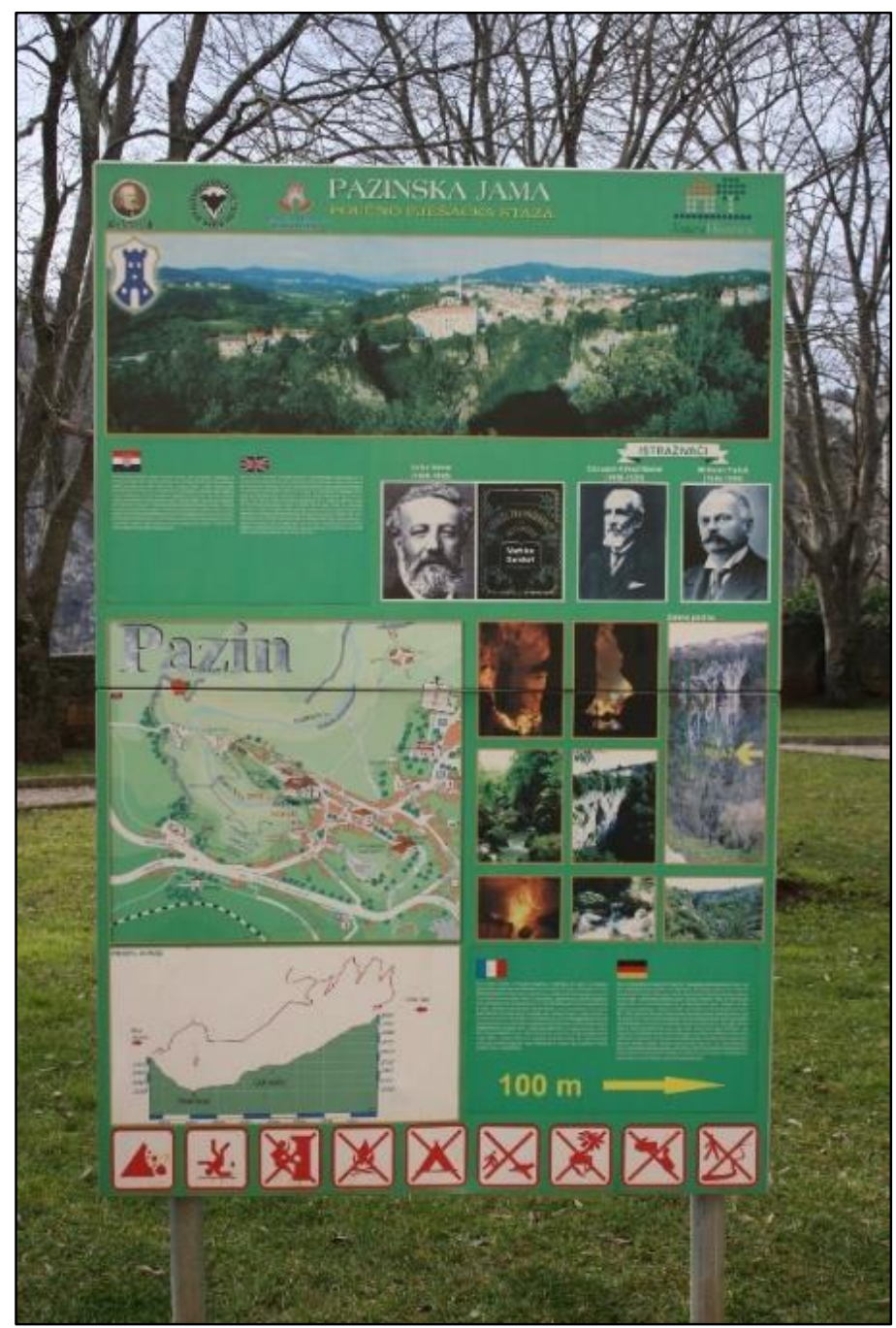

Figura 04. Painel interpretativo sobre o geossítio da Pazinska Jama. Nela é possível conhecer um pouco da história de sua exploração, principais pesquisadores, localização, bem como informações geográficas (Foto: L.E.P. Travassos, 2011).

Construída culturalmente de acordo com experiências e percepções individuais e coletivas a partir de crenças, religiões e contextos socioeconômicos, entre outros, a concepção de patrimônio é muitas vezes dividida entre patrimônio natural e cultural. Contudo, se as caraterísticas geológicas interagirem com os elementos culturais o patrimônio geológico adquire valor cultural sendo, portanto, denominado "sítio 
geocultural". Tais interações dizem respeito a como os processos geológicos influenciam a cultura, como a cultura influencia na percepção e gerenciamento do patrimônio geológico e como se dá a integração entre os patrimônios geológico e cultural (REYNARD, GIUSTI; 2018). Para a área de estudos, mais uma vez sua contribuição como patrimônio é inegável, conforme comprovado por mapas históricos do século XVII e XVIII (Figuras 05 e 06).

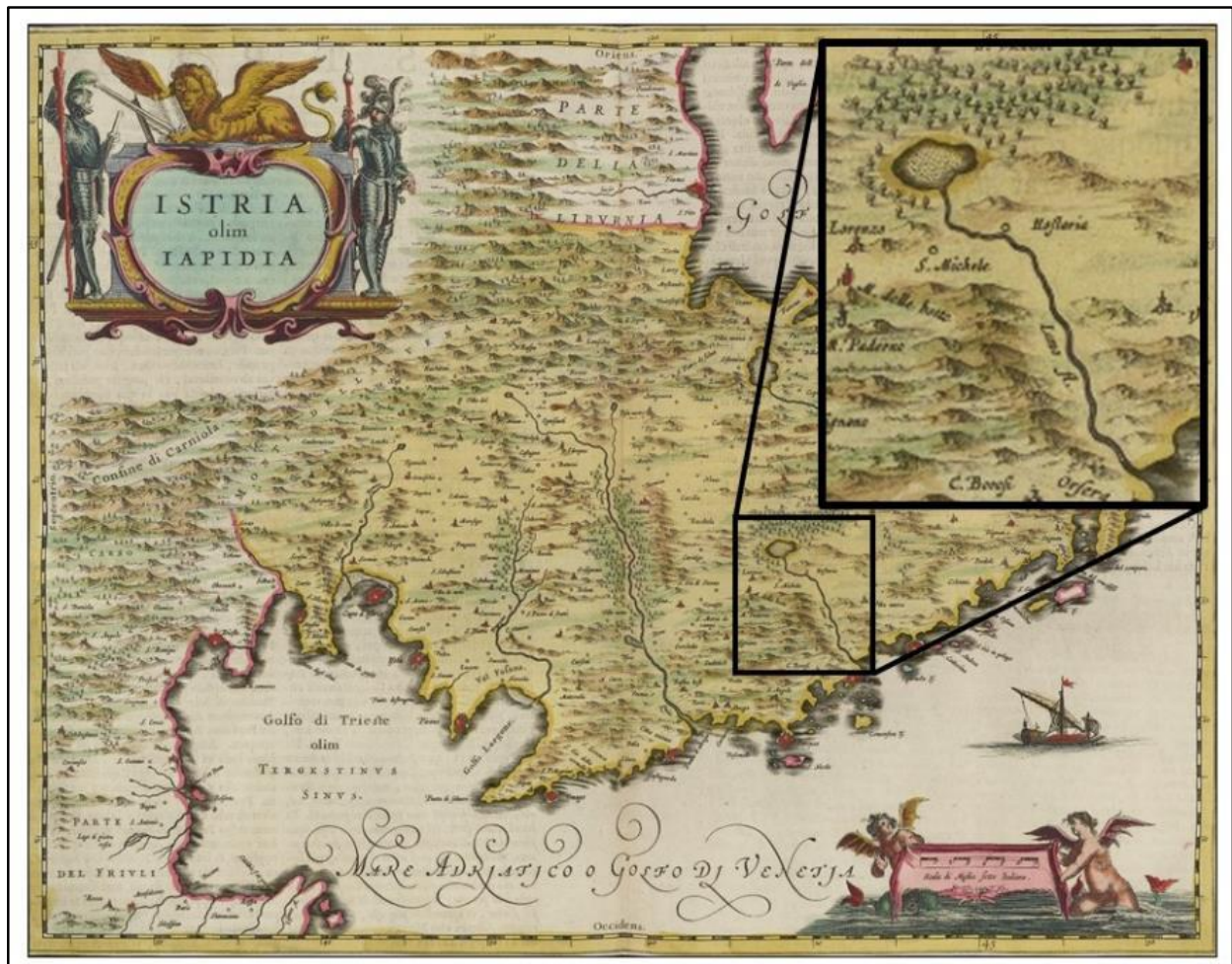

Figura 05. Mapa da região da Ístria, elaborado por Joan Blaeu (1665). No detalhe do mapa é possível observar a grande dolina de Pazin retrata como uma grande abertura que leva as águas daquele local até o Canal de Lemo (Canal de Lim).

Os aspectos culturais do geopatrimônio muitas vezes são destacados nas mais diversas artes, como pintura e literatura, ao buscarem representa-los em suas obras. Tal fato fortalece e difunde os vínculos entre os aspectos naturais de determinada localidade e a cultura de um povo. Não menos importante são as análises geoculturais literárias que permitem estudos comparativos entre paisagens geológicas históricas e contemporâneas a partir de leituras como a de Mathias Sandorf, entre outras. Além disso, auxiliam na compreensão do discurso científico e na percepção cultural de geossítios por diferentes 
autores e em diferentes momentos, o que contribui para a compreensão da evolução do conhecimento e da relação cultura - meio natural da região analisada (REYNARD, GIUSTI; 2018).

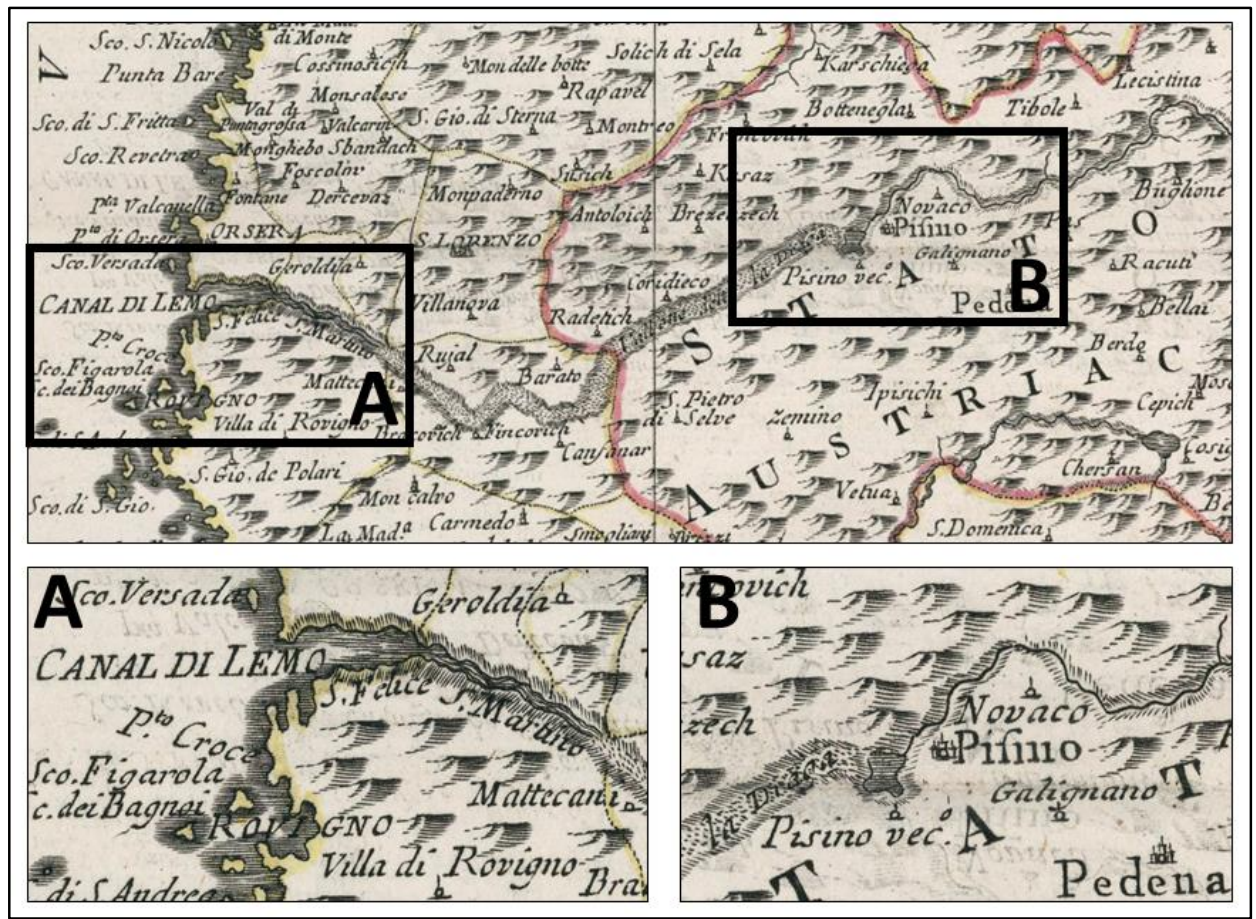

Figura 06. Detalhes da representação do entorno de Pazin e o Canal de Lim, conforme Zatta, Zuliani e Colussi (1784). Em A é possível observar o Canal de Lim e, em B, o detalhe do Rio Pazinčica com seu curso superficial ao norte de Pazin e o sumidouro (Foiba). Após a Foiba, percebe-se o canal fluvial, contudo, sem o curso d água superficial, logo, um vale seco.

\section{Júlio Verne e a Influência da Realidade em suas Obras: O Enredo de Mathias Sandorf}

O escritor francês, Júlio Verne (1828-1905), nasceu em Nantes e iniciou sua trajetória como roteirista e escritor ao se mudar para Paris. Na capital francesa, começou os estudos no campo do Direito para seguir uma carreira semelhante à de seu pai. Contudo, o ambiente parisiense favorecia o contato com artistas, escritores e intelectuais, fato que fez com que Verne traçasse outros caminhos. O jovem francês possuía vocação para leitura e escrita desde a adolescência e se debruçava em livros tanto científicos, quanto não- 
científicos (MOURÃO, 2005, p.1-2). Verne, que viveu na época das grandes descobertas, colheu da ciência, sobretudo, o aspecto criativo (BASSI, 2006).

Barata (2005) e Mourão (2005) afirmam que as contribuições de Verne para o campo da literatura de viagens e/ou dos romances são de grande importância. Seus textos são um misto de descrições científicas e imaginativas que seguiam os aportes bibliográficos que o autor acumulava durante sua vida. Teve como referências autores literários como Edgar Allan Poe (1809) e Daniel Defoe (1660). O primeiro tinha um estilo romancista sombrio que era um misto de fantasia, mistério e horror. Defoe, famoso pelo seu livro Robinson Crusoé, escreveu contos que associavam imaginação, exploração e descrição geográfica.

No tocante aos viajantes e exploradores que serviram de base para Verne, destacam-se os Irmãos Pizarro, Pedro Teixeira, La Condamine e Alexander von Humboldt (MOURÃO, 2005), este último extremamente importante para a Geografia e as Ciências Naturais, conforme afirmam Turley (2001), Pratt (2001), Riesco Jr. (2004), Kohlhepp (2006), Rodaway (2007) e Travassos (2013). Ainda sobre Humboldt, Ricotta (2003) destaca que era um cientista preocupado com a forma de tratamento da linguagem e seu efeito sobre leitor, pois realizava descrições minuciosas da paisagem e dos processos físicos e humanos que observava, levando narrativas com riqueza de detalhes ao leitor.

Talvez por essa razão as obras de Verne também levem ao leitor grande riqueza de detalhes e, na maioria das vezes, veracidade dos fatos geográficos. Sobre essa geografia nas obras de Júlio Verne, nas viagens, Mourão (2005) ressalta a inserção da diversidade dos conhecimentos geográficos que permeia todos seus romances. São, portanto, romances geográficos.

Enquanto vivo, Júlio Verne publicou mais de cem trabalhos entre ensaios, dramas teatrais, poemas e os conhecidos livros de aventura inspirados pela ciência. Este último gênero literário foi inaugurado com o livro Cinco semanas em um balão, publicado em 1863 (BASSI, 2006).

Muito embora ocorram debates sobre o romantismo, não é possível negar que as contribuições para o entendimento da natureza foram de grande valor, tanto para a ciência quanto para as artes. Os autores afirmam que isso fica claro quando se percebe as representações da paisagem tendo a natureza como a figura central, ganhando destaque nas representações artísticas desde o século XVI, mas atingindo sua máxima manifestação a partir do século XIX (CENE; FERRAZ, 2016, p.225-226).

Na primeira parte do livro Mathias Sandorf, foco principal deste trabalho, a região retratada por Júlio Verne fazia parte do Império Austro-húngaro. O romance tem início em Trieste (atual, Itália), onde membros da nobreza húngara, o conde Mathias Sandorf e seus associados, Stephen Bathory e Ladislav Zathmar, planejam uma insurreição para que a Hungria se separe da monarquia. Durante seus preparativos, o pombo-correio do conde é interceptado por acaso por Zirone e Sarcany, dois criminosos da região. No cilindro de mensagens do pombo, eles encontraram uma mensagem 
criptografada e Sarcany, o traiçoeiro secretário do banqueiro Silas Thoronthal, usa sua posição para roubar uma mesa decodificadora para que pudessem decifrar a mensagem.

Enquanto isso, Thoronthal vinha tentando se apropriar do dinheiro de Sandorf. Ao ver que uma conspiração política está em andamento, Thoronthal e Sarcany alertam a polícia que acaba por prender os três conspiradores: Sandorf, Bathory e Zathmar. Uma grande recompensa é dada aos dois informantes por sua "lealdade" e cada um recebe metade do dinheiro de Sandorf.

A polícia austríaca leva os presos para o Castelo de Pazin (atual Croácia), onde são condenados à morte. Esperando pela sua execução, por causa de um efeito acústico que transferia o som de uma sala do castelo para a cela em que estavam, os condenados acabam por escutar uma conversa entre os traidores. A partir de então, ao invés de se entregarem ao destino, decidem fugir da prisão e se vingar. Os três prisioneiros quebram as barras da janela do castelo e Sandorf sobe pela janela para descer pelo para-raios que chega até a base da muralha.

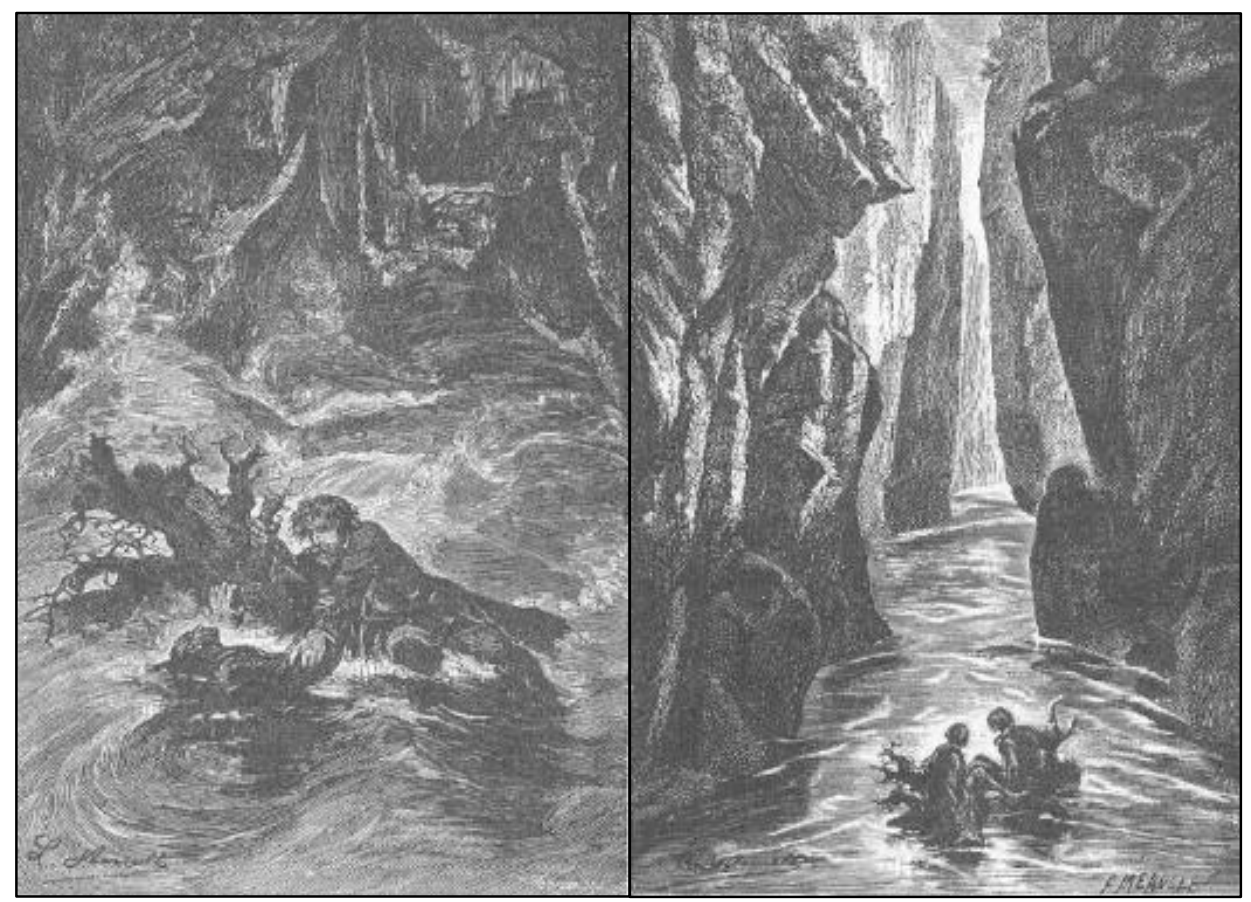

Figura 07. Sandorf e seu amigo segurando ao trocno para sobreviverem à corrente do Rio Pazinčica em ilustração de Léon Benett. 
Enquanto isso, a polícia entra na cela e captura Zathmar. Sandorf e Bathory continuam sua fuga, mas um relâmpago atinge o para-raios e eles caem na torrente furiosa da caverna (Rio Pazinčica), que os leva para a entrada da Pazinska jama (Caverna de Pazin) e o desconhecido subterrâneo. Durante a fuga da fortaleza, não sabiam onde estavam e, portanto, não conseguiam imaginar para onde as águas do rio os levariam. Agarrando-se a um tronco de uma árvore (Figura 07), Sandorf e Barthory são levados pelo Pazinčica para o subterrâneo por cerca de seis quilômetros e, finalmente, o rio subterrâneo os traz de volta à superfície na sua foz no Canal de Lim (Figura 08).

A partir do canal, Sandorf e Barthory caminham para Rovinj, onde encontram abrigo seguro na casa de um pescador, Andrea Ferrato. Infelizmente, são traídos por um inimigo do pescador, de nome Carpena. Sob uma rajada de balas, os dois personagens escapam para a praia, local onde Bathory cai e é capturado. Com as balas ainda voando ao redor dele, Sandorf salta da borda de um alto penhasco de Rovinj, em direção ao mar, desaparecendo nas ondas.

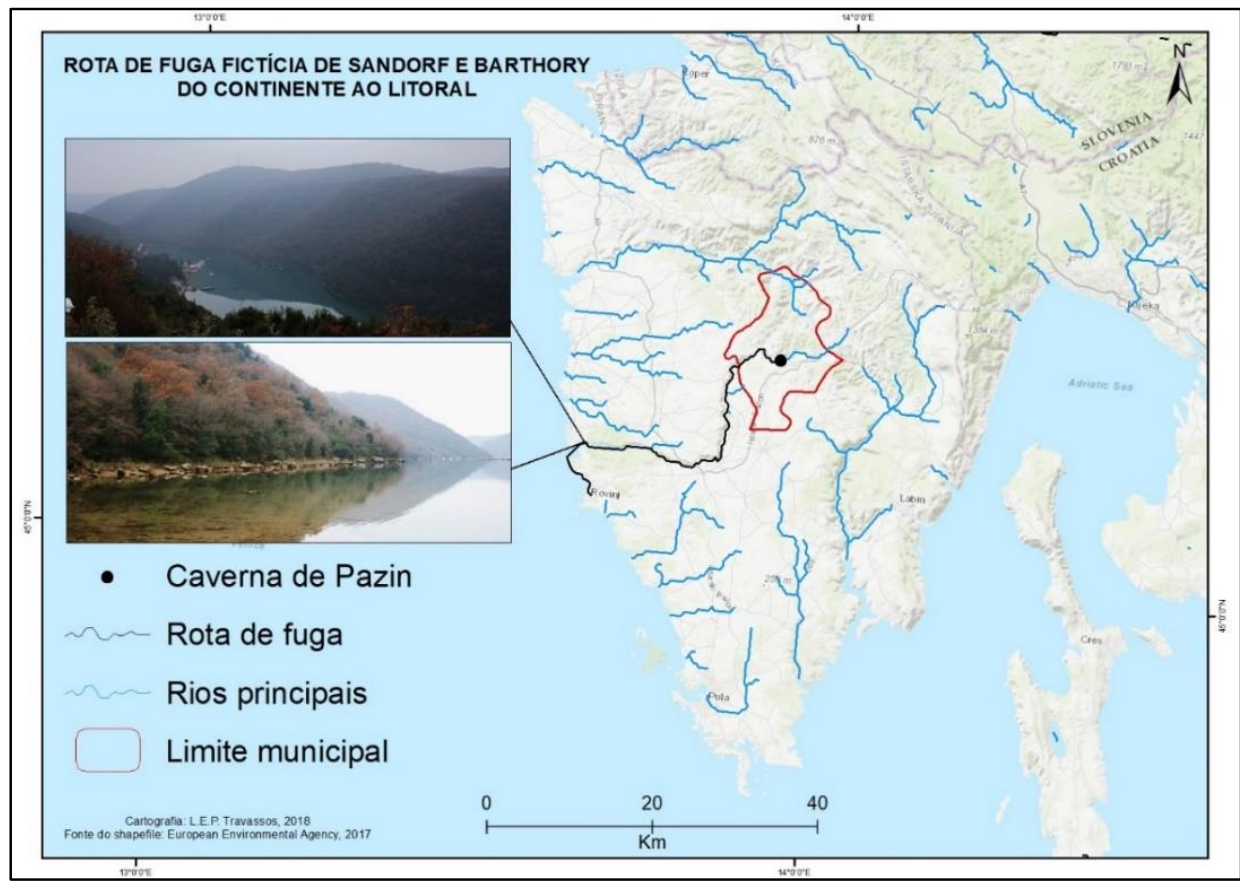

Figura 08. Mapa de localização do Canal de Lim (Limski Kanal, Croácia). Na primeira foto é possível ver, ao final do canal, o Mar Adriático. Atualmente sabe-se da existência de uma caverna, a Rumualdova Špilja. No entanto, a caverna possui 360 metros e não apesenta ligação comprovada com a Pazinska Jama. 
Bathory é levado de volta ao Castelo de Pazin e executado junto com Zathmar no dia seguinte. $\mathrm{O}$ banqueiro Thoronthal e seu colaborador Sarcany começam uma vida nova com seus ganhos ilícitos. O primeiro se muda para Dubrovnik e o segundo para região de vários cassinos ao longo da costa do Mediterrâneo.

A segunda parte do romance avança quinze anos e começa na cidade de Dubrovnik, Croácia. É lá que aparece um misterioso Dr. Antekirtt. O doutor, rico e renomado médico, não é outro senão o Conde Mathias Sandorf que começa sua vingança contra aqueles que o traíram (Thorontal, Sarcany, Zirone e Carpena) e que causaram a morte dos outros revolucionários húngaros. Nos últimos capítulos do romance, seguemse as aventuras por lugares como Dubrovnik, a base do Monte Etna, na Sicília, a ilha de Malta, as ilhas de frente para a costa da Líbia, Monte Carlo, Gibraltar, bem como a Tunísia e Marrocos.

Ainda que a segunda parte do romance não seja o foco principal deste artigo, destaca-se que vários lugares retratados continuam tendo o carste como cenário da estória.

\section{O Carste Croata pela Ciência e pela Visão de Júlio Verne}

A região conhecida como Carste Dinárico engloba partes da Eslovênia, Croácia, Bósnia e Herzegovina, Sérvia, Kosovo, Albânia e Macedônia, bem como a totalidade do território de Montenegro. A paisagem pedregosa da região sempre foi considerada inóspita e povoava o imaginário europeu. Em vários relatos de viagens do século XVII ao XIX, têm-se a falta de água superficial, a seca, os ventos fortes e as rochas como centro das narrativas (Figura 09).

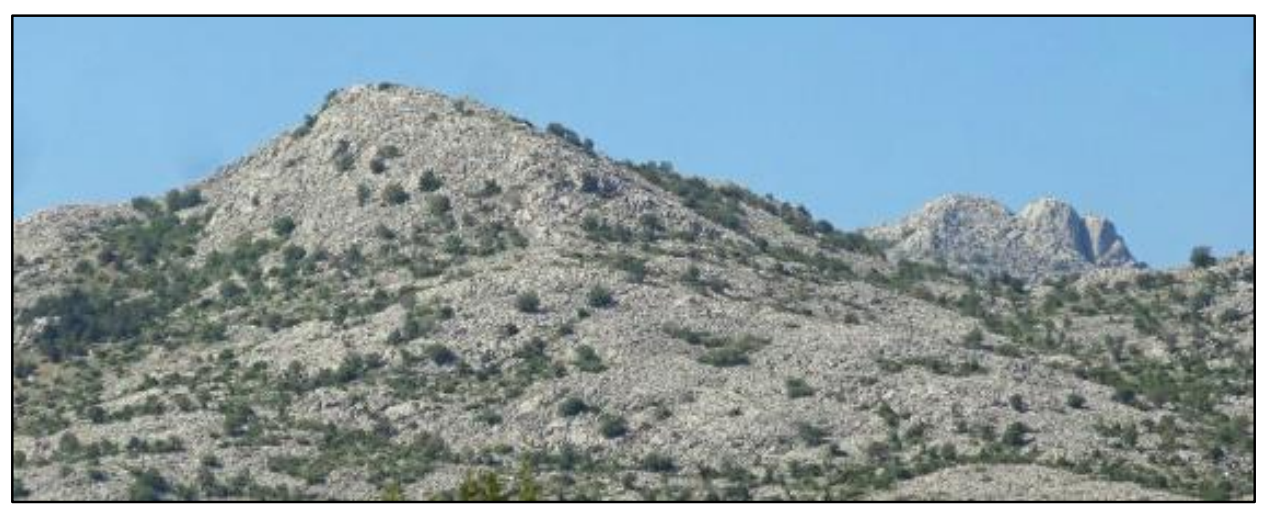

Figura 09. Aspecto geral do Carste Dinárico na Croácia e as "rochas supérfluas" das Montanhas Velebit (Foto: L.E.P. Travassos, 2016).

Um viajante que fez uma descrição topofóbica do Carste Dinárico foi Richard Francis Burton (1821-1890). Sua experiência com o carste foi resumida da seguinte 
maneira: “(...) um estranho passando em um trem diria que, quando Deus Todo Poderoso terminou de criar a Terra, Ele jogou todas as rochas supérfluas aqui" (BURTON, 1893, p.26).

Inspirado por sua viagem de barco e pela leitura de obras científicas, Verne certamente reconheceu as características principais desse tipo de relevo, seja por sua própria vivência, seja pela percepção de Yriarte (1878), conforme figura 10.

Especificamente em Mathias Sandorf, a região mais retratada na primeira parte do romance é a Ístria, região natural e histórica conhecida desde o Império Romano e, desde 1947, disputada por eslovenos e croatas. Do ponto de vista estrutural e morfológico, Ambert (1978) afirma a região é dividida em Ístria Branca (blache), Cinza (grize) e Vermelha (rouge), conforme figura 11. Ambert (1978) e Nicod (2003) destacam o caráter montanhoso e muito tectonizado da Ístria Branca, em contraposição à zona sinclinal dissecada por dolinas da Ístria Cinza. Por fim, mais em direção ao sul-sudoeste, surgem os terrenos muito carstificados da Ístria Vermelha que fazem parte da Placa Adriática.

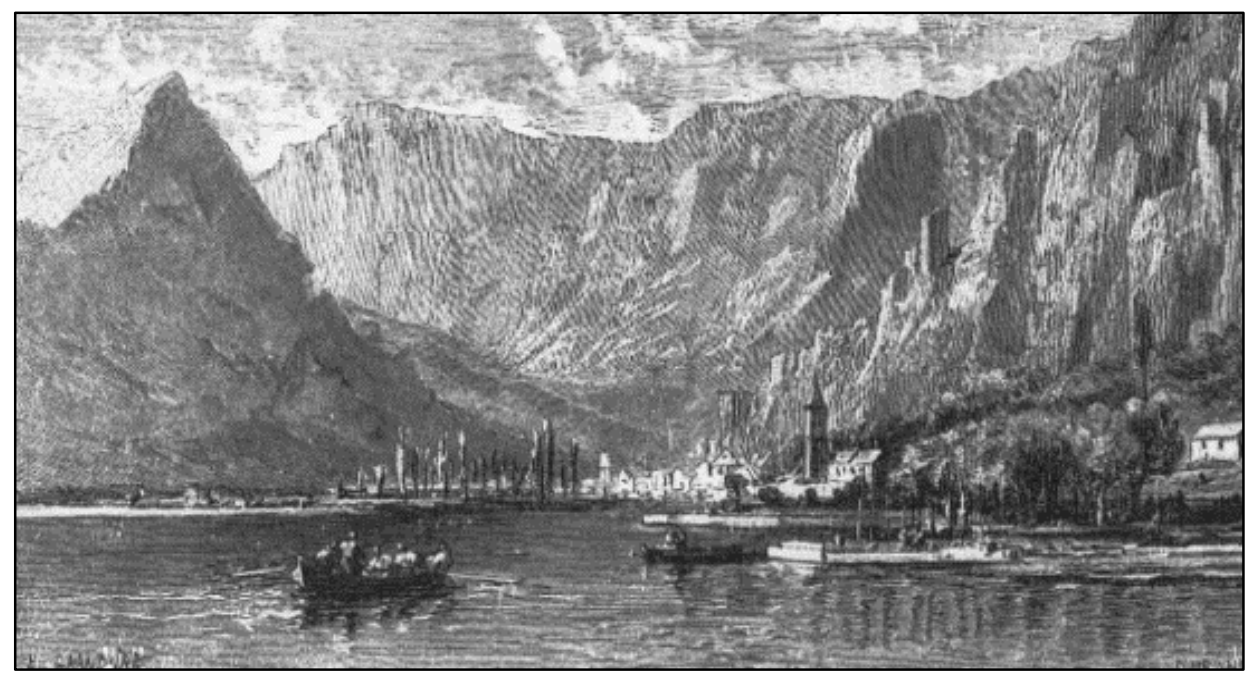

Figura 10. Aspectos da paisagem cárstica em Yriarte (1878). Certamente foram as paisagens vistas durante o cruzeiro que Verne fez no Adriático aliadas às descrições deste autor que inspiraram o cenário natural retratado em Mathias Sandorf. 

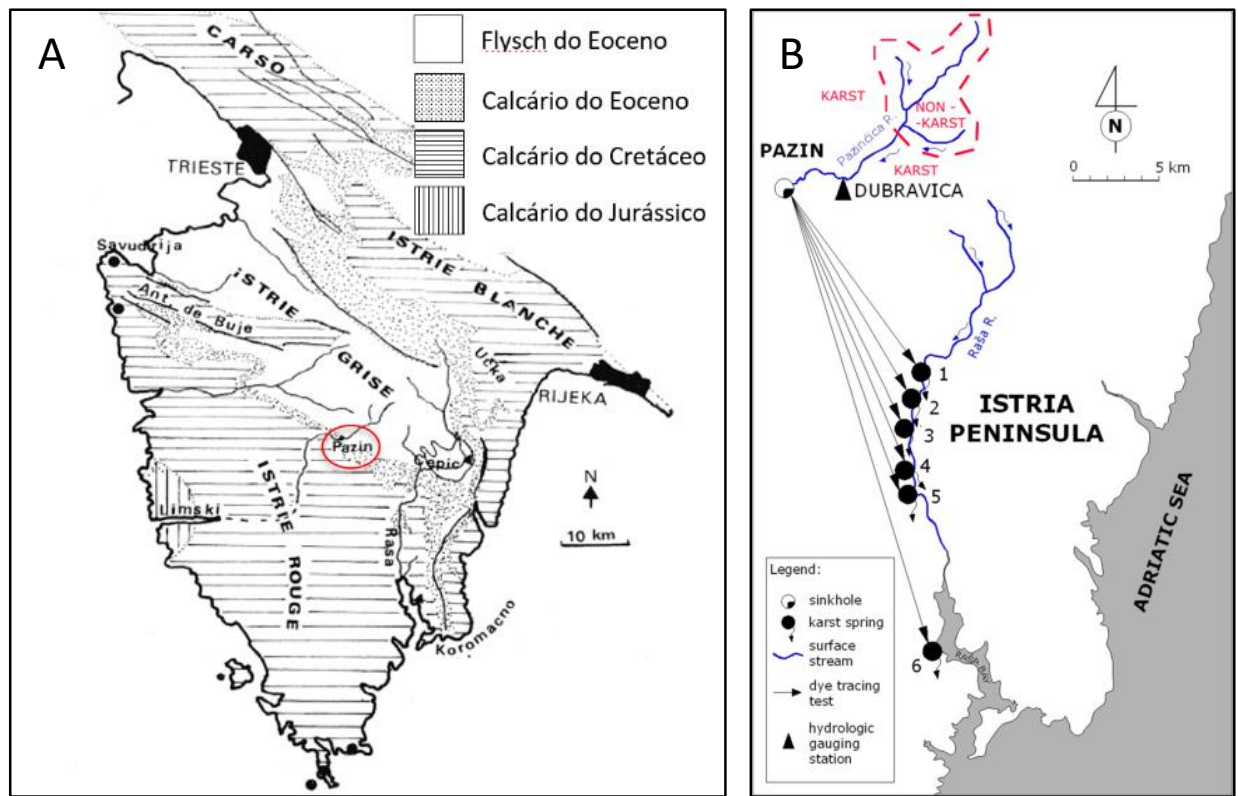

Figura 11. A) Divisão geológica, estrutural e geomorfológica da Ístria. O círculo indica a localização de Pazin, no contato entre oflysch impermeável e o calcário, ambos do Eoceno (Fonte: Adaptado de Ambert, 1978, p.48). Em B tem-se a comprovação da ligação subterrânea entre a Caverna de Pazin e o Canal ou Baía de Raša, na costa leste croata (Fonte: BONACCI, 2015, p.43)

Com o trabalho de campo e por meio da leitura de Bonacci (2015), percebe-se que o Rio Pazinčica representa o exemplo de um rio superficial inicialmente não cárstico, que flui por terrenos impermeáveis e não carstificados. Contudo, após chegar aos carbonatos, desenvolve-se para a jusante como um importante rio cárstico. Formado por três afluentes menores, penetra o vale de Pazin pelo Norte em direção ao sul.

A região de Pazin já povoou o imaginário coletivo quando inúmeros mitos e lendas da Ístria deram nome a vários rios e "explicaram” a formação de alguns fenômenos cársticos como os vales secos, as grandes dolinas e as cavernas. Crnko, Rubinić e Malečkar (2015) lembram a lenda do gigante Dragonja que teria sido o responsável pela formação da Caverna de Pazin e do Rio Pazinčica, pois usou toda sua força para arar a terra através da qual a água começou a fluir por uma paisagem rochosa e escarpada.

A feição geológica que foi "elaborada pelo gigante" pode ser, na verdade, tanto uma falha desenvolvida nos calcários cretáceos da região, quanto o vale seco existente na região e que já era retratado no mapa de Zatta, Zuliani e Colussi (1784). Kuhta (2011) afirma que os $82,9 \mathrm{~km}^{2}$ da bacia de drenagem do Rio Pazinčica são compostos por terrenos impermeáveis e, por esse motivo, o rio recebe um grande volume d’água que entra no 
sumidouro da caverna com muita força e ao longo da falha mencionada. Possui, portanto, um caráter torrencial. Malez (1968, p.76), já destacava o sumidouro deste rio como um dos mais importantes fenômenos espeleológicos de todo o Carste Dinárico. Além das pesquisas de Martel (1894; 1896; 1897), o livro Duemila Grotte (BERTARELLI; BOEGAN, 1926) apresenta descrições da caverna, bem como o mapa da caverna em perfil e planta baixa, além das sessões dos condutos. É na verdade, uma reprodução do primeiro mapa publicado em Martel (1894).

Em relação à dinâmica hídrica regional, Bonacci (2015) afirma que as primeiras teorias científicas válidas sobre o comportamento da água no carste foram desenvolvidas como parte das investigações ao longo do Carste Dinárico no final do século XIX e no começo do século XX, com os trabalhos pioneiros de Jovan Cvijić, em 1893. Especificamente sobre a Caverna de Pazin, Cvijić (1895/2017, p.103) destaca o fato de o Rio Foiba (Pazinčica), perto de Pazin, desaparecer em um enorme sumidouro.

A partir do Castelo de Pazin, Júlio Verne afirma que a sua torre está localizada ao lado de uma "planura que terminava abruptamente a cidade (...)" e se alguém se debruçasse no parapeito do abismo, conseguiria ver "um abismo largo e profundo, cujas paredes escarpadas são revestidas de comprida vegetação. Numa palavra, era o abismo que atrai e fascina e que não restituía nada do que ali se arremessasse" (VERNE, $1885 / 1965$, p.40)

Verne afirma que, na região, o abismo é chamado de Buco e "serve de recipiente às cheias de um ribeiro (...). O ribeiro despeja-se em uma caverna que a água foi cavando pouco a pouco, através das rochas e na qual se engolfa com impetuosidade". Descreve, assim, seu caráter torrencial. Além desta descrição, menciona dúvidas quanto a hidrogeologia perguntando para "onde vão essas águas, passando por debaixo da cidade? Ignora-se. Onde reaparecem? Não se sabe. Desta caverna, ou antes, deste canal, (...) nem se conhece a extensão, nem a altura, nem a direção" (VERNE, 1885/1965, p. 40).

Atualmente, graças às pesquisas de Edourd-Alfred Martel e Wilhelm Putick (1893), Carlo D’Ambrosi (1920), Mirko Malez (1967) e Mitar Marinović (1975) sabe-se que a extensão da estrutura da entrada, logo abaixo do paredão vertical até o final do lago do sifão é de 215 metros a uma profundidade de 12 metros. A entrada do sumidouro está localizada a aproximadamente 185 metros acima do nível do mar e mergulhadores comprovaram que ao final do sifão, no nível de base hídrico, tem-se 173 metros acima do nível do mar (KUHTA, 2011), conforme figura 11. 


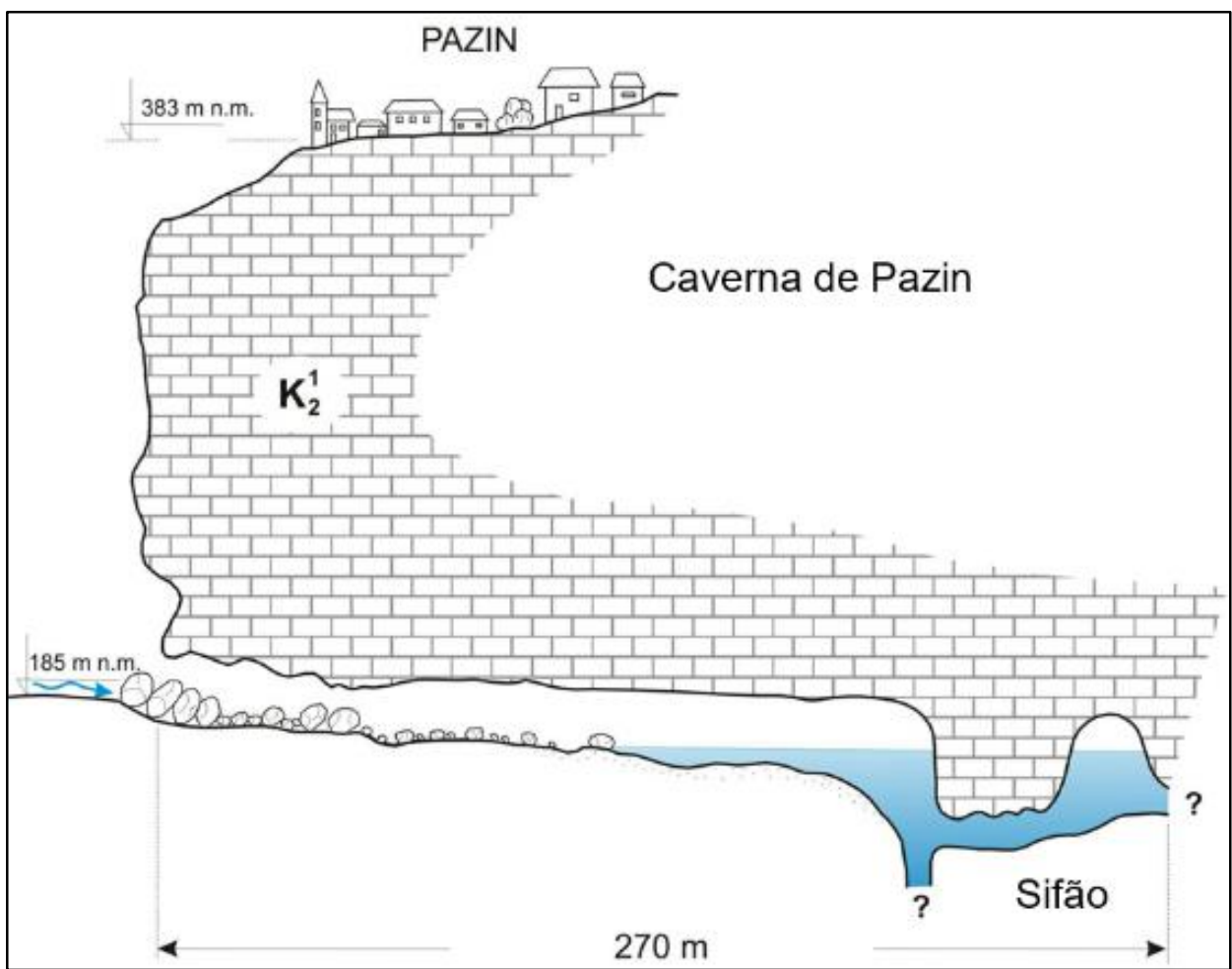

Figura 11. Perfil da Caverna de Pazin conforme elaborado por Malez (1968) e pelos mergulhadores de Pazin, em 1975. Digitalizado por Božičević (1985). Adaptado pelos autores de Kutha e Stroj (2010, p.27)

Após descrever a queda de Sandorf e Bathory que desciam pelo para-raios, Júlio Verne apresenta um pouco do interior da caverna ao acompanhar o movimento dos dois personagens pelo subterrâneo:

Se a claridade do dia penetrasse na caverna, poderia observar e estudar o estado das águas e sua direção. Mas coisa alguma lhe indicava que estivesse próximo de alcançar o fim desse interminável canal [...]. Quanto à velocidade, podia calcular-se, pelo menos, em três léguas por hora, se fosse igual à da torrente que o arrastava" (VERNE, 1885/1965, p. 47)

Por causa da altura da queda e da força das águas, os dois personagens achavam que os inimigos possivelmente acreditariam que os prisioneiros encontraram "a morte nas águas deste abismo" e, certamente, ninguém tentaria persegui-los. Para eles, "seja qual for o lugar aonde for desaguar esta torrente, mar ou ribeira, lá chegaremos e chegaremos vivos! "(VERNE, 1885/1965, p. 48). 
Em termos morfológicos, o mapa da caverna que foi elaborado após a publicação de Mathias Sandorf demonstra que sua estrutura é simples, apresentando um conduto amplo com cerca de 10 metros de largura que se estende em direção sudeste. Para o romance, Verne $(1885 / 1965$, p.48) descrevia o canal se alargando e, por isso, as águas "corriam com maior moderação. Talvez se pudesse concluir que a extremidade dessa abertura subterrânea não devia estar muito longe (...), as paredes se distanciavam, a abóbada tendia a abaixar".

Na verdade, a caverna termina em um lago subterrâneo (Lago de Martel), com 80 metros de comprimento e cerca de 20 metros de largura. Até o sifão deste lago, a profundidade varia entre 2 e 13 metros. Entretanto, uma exploração subaquática, em 1975, mapeou a passagem alagada após o sifão que apresenta uma extensão de aproximadamente 70 metros (KUHTA, 2011).

No livro, Sandorf calculava que com a diminuição da velocidade da corrente, ou poderiam sair vivos ou poderiam morrer. Quando o teto da caverna ia abaixando, os personagens calculavam friamente o que podia acontecer com o contínuo rebaixamento: "Tinha já escapado deitando-se de costas, todas as vezes que a sua mão encontrava as saliências das rochas (...). E se o canal subterrâneo fosse afunilando-se assim num longo percurso, seria possível sair dali vivo?" (VERNE, 1885/1965, p.49).

Pelo que os dados atuais nos informam, provavelmente não. Além disso, caso sobrevivessem, Sandorf e Bathory não sairiam na costa oeste e, sim, na costa leste fluindo pelo Rio Raša até o mar (Figura 12).

Ainda assim é interessante destacar o que é lembrado por Bassi (2006): a descrição da fuga de Sandorf parece ter sido inspirada nas narrativas daqueles exploradores que desceram as Gargantas do Verdon ou naquelas dos exploradores do Rio Timavo.

Hoje sabe-se que o Timavo nasce nas montanhas eslovenas e flui subterraneamente por cerca de $40 \mathrm{~km}$ para desaguar no Mar Adriático, próximo à Duino, na Itália. Édouard-Alfred Martel explorou ambos locais e no Timavo, utilizou um precário barco para suas pesquisas. Além destes dados, Bassi (2006) destaca que 40 anos antes da publicação de Mathias Sandorf, Federico Lindner desceu a mais de 300 metros de profundidade no Abismo Trebiciano (Jama Labodnica), em Trieste, encontrando o Rio Timavo abaixo da superfície cárstica. 


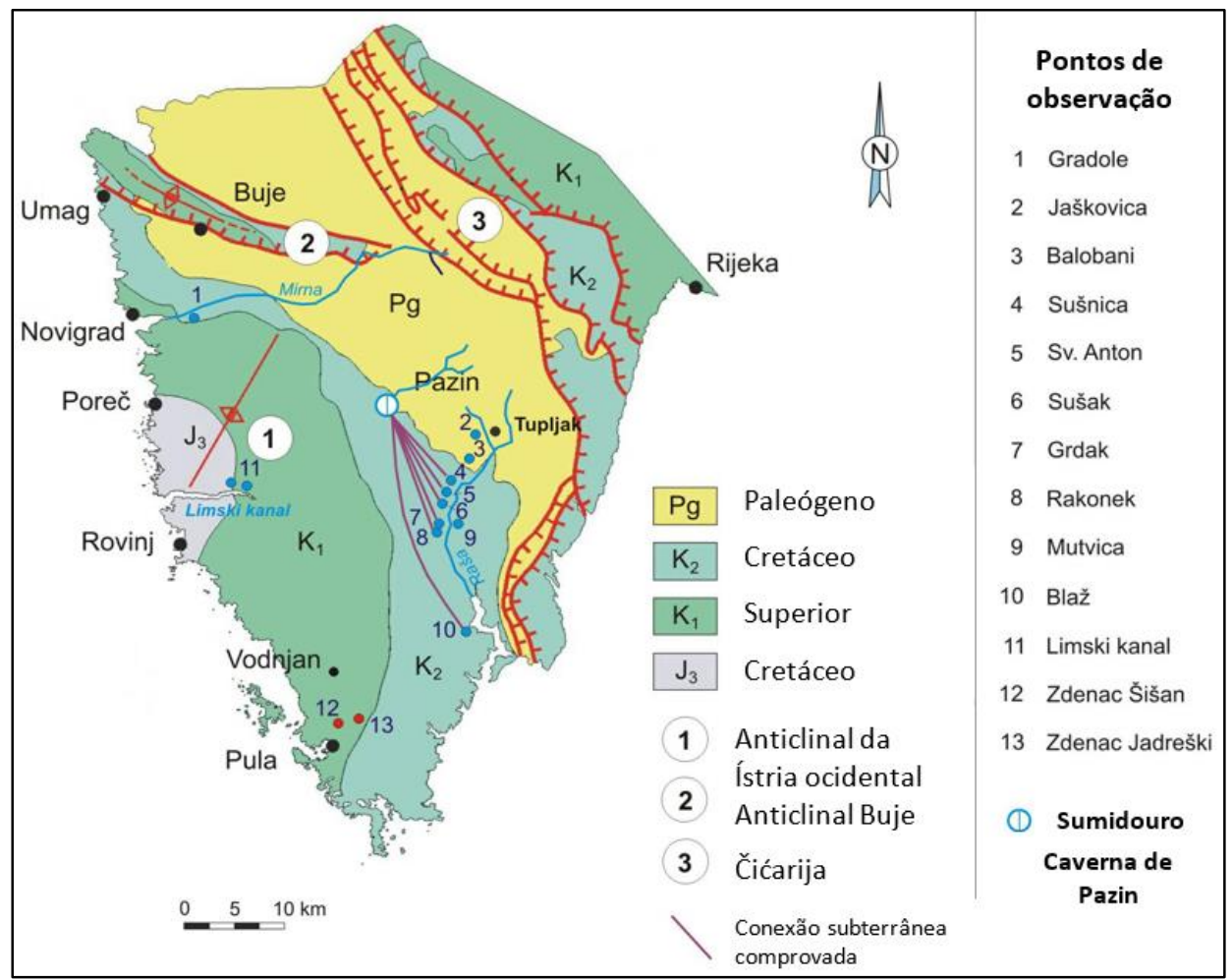

Figura 12. Mapa geológico simplificado da Ístria com as conexões subterrâneas a partir da Caverna de Pazin. No mapa também foram plotados os pontos de observação e monitoramento após o acidente ambiental de 1997 (Fonte: Adaptado de Kutha e Stroj, 2010, p.30)

Assim, a segunda metade do século XIX foi um importante período para as descobertas espeleológicas e destaca-se o ano de 1851, quando Adolf Schmidl pesquisa cientificamente a bacia do Timavo por ordem da Coroa Austríaca para o suprimento de água durante a construção da ferrovia que ligaria Ljubljana (Eslovênia) a Trieste (Itália). Além dessa data, vale destacar que 1884 (apenas um ano antes da publicação de Mathias Sandorf), o recém-criado Clube Alpino Alemão e Austríaco (Deutschen und Österreichischen Alpenvereins), de Trieste, começou a maior expedição espeleológica já realizada até então com a exploração do rio subterrâneo de San Canziano (nas Cavernas de Škocjan, Eslovênia) quando foi possível superar a sexta cachoeira, o limite do trecho então conhecido (KRANJC, 1997; 2006; TRAVASSOS; KOHLER; KRANJC, 2006; BASSI, 2006). 


\section{Considerações Finais}

Com o exposto, obviamente percebe-se que as contribuições de Júlio Verne com a publicação de Mathias Sandorf não foram, em nenhum momento, contribuições espeleológicas ou carstológicas. Entretanto, é inegável a criação de uma narrativa inspiradora no tocante ao mundo subterrâneo.

Parece que as explorações no Rio Timavo, bem como os trabalhos científicos da época foram o principal "combustível" para a criatividade do autor. Ainda que a comprovação da conexão com o mar tenha surgido apenas em 1927, desde a Antiguidade Clássica geógrafos, poetas e historiadores (e.g. Estrabão, Virgílio e Tito Livio) já teorizavam sobre a possível conexão daquele rio.

A pesquisa demonstrou que a narrativa de Júlio Verne em Mathias Sandorf constitui uma efetiva forma de conhecer a percepção de um homem de seu tempo quanto às feições cársticas croatas e como estas atuavam no imaginário e nas práticas cotidianas da sociedade e indivíduos daquele momento. Sendo a obra também fruto de análises de obras lidas pelo autor acerca do geopatrimônio em questão, também foi possível perceber, em determinado grau, o discurso científico daqueles autores e da ciência naquele momento. Portanto, percebe-se tanto a valorização cultural, quanto científica desse geopatrimônio por meio da difusão dos aspectos naturais, histórico-culturais e científicos da região.

\section{Agradecimentos:}

Os autores reconhecem e agradecem o auxílio do Prof. Dr. Nenad Buzjak, do Departamento de Geografia da Universidade de Zagreb (Croácia), que disponibilizou referências sobre a Caverna de Pazin e seu entorno. Além dele, agradecem ao Prof. Dr. Andrej Mihevc, do Instituto de Pesquisas do Carste (Eslovênia), pelo auxílio no trabalho de campo na região da Ístria, Croácia. Ao Sr. Leon Drame e ao Dr. Trevor Shaw, também membros do Instituto de Pesquisas do Carste (Eslovênia), nosso agradecimento por terem enviado o mapa elaborado por Martel e Putick em qualidade melhor do que a que possuíamos em nossos arquivos.

\section{Referências}

AMBERT, M. Le littoral de l'Istrie: premières observations géomorphologiques. Méditerranée, v. 32, n. 1, p. 47-56, 1978.

AMORIM FILHO, O.B. Literatura de explorações e aventuras: as "Viagens Extraordinárias" de Júlio Verne. Sociedade \& Natureza, Uberlândia, v.20, n.2, p. 107-119, dez. 2008.

AUGUSTIN, G. Um novo viajante na literatura de viagem. Linha D'Água, n. 19, p. 13-32, 2006. 
AULER, A.; PILÓ, L. B. Introdução à Espeleologia. In: ICMBio/ CECAV (Org.). III CURSO DE ESPELEOLOGIA E LICENCIAMENTO AMBIENTAL. Brasília: ICMBio/ CECAV, 2011. p. 7-23.

BARATA, G. Júlio Verne: Centenário da morte do pai da ficção científica. Ciência e Cultura, v.57, n.2, p. 56-57, 2005.

BASSI, S. Divagando sottoterra con Giulio Verne. Speleologia, v.26, n.53, p.44-46, 2006.

BERTARELLI, L.V.; BOEGAN, E. Duemila grotte: quarant'anni di esplorazioni nella Venezia Giulia. Milano: Touring Editore, 1926.

BLAEU, J. Istria olim Iapidia. Amsterdam: Joan Blaeu, 1665. Disponível em: <https://www.davidrumsey.com/> Acesso em 08 jun. 2018.

BOGNAR, A. Geomorfološke značajke, nastanak i razvoj doline potoka Pazinčice [Geomorphological Features, Origin and Development of the Pazinčica River Valley]. In: LENIĆ, B. Prirodoslovna istraživanja riječkog područja II. Rijeka: Prirodoslovni muzej Rijeka, 2009. p.111-125.

BONACCI, O. Karst hydrogeology / hydrology of dinaric chain and isles. Environmental Earth Sciences, v. 74, n. 1, p. 37-55, 2015.

BRILHA, J. Geoheritage: inventories and evaluation. In: REYNARD, E., BRILHA, J. (Org.). Geoheritage: Assessment, Protection, and Management. Elsevier: Amsterdam, 2018. p.69-86.

BROU, B. Léon Benett, illustrateur de Jules Verne en Nouvelle-Calédonie. Le JV, n.22, p.13$18,1992$.

BURTON, I. The Life of Captain Sir Richard. F. Burton. London, Chapman \& Hall, 1893 (2 volumes).

CENE, V.R.; FERRAZ, M.K. Geografia e arte: um debate epistemológico sobre suas relações. In: SUZUKI, J.C.; LIMA, A.P.de; CHAVEIRO, E.F. Geografia, literatura e arte: epistemologia, crítica e interlocuções. Porto Alegre: Imprensa Livre, 2016. p.220-246.

CRNKO, T.; RUBINIĆ, J.; MALEČKAR, F. Relationship between man and water throughout History. In: HAJNA, N.Z. LIFE and water on Karst: monitoring of transboundary water resources of Northern Istria. Ljubljana: Založba ZRC, 2015. p.82-91.

CVIJIĆ, J. CARSTE: Uma monografia geográfica (1895). Belo Horizonte: PUC Minas, 2017. Tradução de Luiz Eduardo Panisset Travassos. Revisão João Henrique Rettore Tottaro.

GRAD Pazin, s/d. Disponível em: <https://www.pazin.hr/o-pazinu/povijest/ pazin/> Acesso em 25 mai. 2018.

ISTRA Culture. La foiba di Pisino, 2015. Disponível em: <http://www.istriaculture.com/it/la-foiba-di-pisino-i116> Acesso em: 22 mai. 2018. 
KOHLHEPP, G. Descobertas científicas da Expedição de Alexander Von Humboldt na América Espanhola (1799-1804) sob ponto de vista geográfico. Revista de Biologia e Ciências da Terra, v.6, n.1, p.260-278, 2006.

KRANJC, A. Introduction. In: KRANJC, A. (Ed.). KRAS: Slovene Classical Karst. Ljubljana: ZRC SAZU, 1997. p. 07-17.

KRANJC, A. Kras - Classical Karst (Slovenia-Italy) In: SIMPÓSIO NACIONAL DE GEOMORFOLOGIA/REGIONAL CONFERENCE ON GEOMORPHOLOGY, 6, 2006, Goiânia. Proceedings... Gôiania: IAG/UGB, 2006. p. 6.

KUHTA, M. Pazinska Jama and its impact on the quality of springs in the valley of the river RAŠA. In: PRELOVŠEK, M.; HAJNA, N. Z. Pressures and protection of the underground karst: cases from Slovenia and Croatia. Postojna: Inštitut za raziskovanje krasa, 2011. p.128137.

KUTHA, M.; STROJ, A. Primjeri incidentnih onečišćenja speleoloških objekata tekućim ugljikovodicima i njihove posljedice / Accidental pollution of the caves by liquid hydrocarbon - examples and consequences: In: BUZJAK, N.; PAAR, D.(ed.). Stručni seminar o zaštiti špilja i podzemne faune. Samobor: Speleološki klub "Samobor", 2012. p.2438.

MAGDALENIĆ, A.; VAZDAR, T.; HLEVNJAK, B. Hydrogeology of the Gradole Spring Drainage Area in Central Istria. Geologia Croatica, v.48, n.1, p. 97-106, 1995.

MALEZ, M. Ponor Pazinčice i njegova uloga u podzemnom hidrološkom sistemu srednje i južne Istre. Hrvatski geografski glasnik, v.30, n.1., p. 61-76, 1968.

MARTEL. E.A. La Foiba de Pisino. Paris: La Nature, 1897.

MARTEL. E.A. Les abîmes: les eaux souterraines, les cavernes, les sources, la spéléologie. Paris: Delagrave, 1894.

MARTEL. E.A. Sur de la Foiba Pisino (Istria). Compt. Rend. de Acad. des Sciences, v.123, n.28, 1896.

MOURÃO, R.R.de F. Cem anos da morte de Júlio Verne. Porto Alegre: Instituto Histórico e Geográfico do Rio Grande do Sul, 2015. Disponível em: <http://www.

ihgrgs.org.br/artigos/contibuicoes/Ronaldo\%20R.\%20de\%20F.\%20Mour\%C3\%A3o\%20$\% 20$ Cem\%20Anos\%20da\%20Morte\%20de\%20Julio\%20 Verne.pdf $>$ Acesso em: 25 mai. 2018.

MURRAY, M. Geodiversity. In: REYNARD, E., BRILHA, J. (Org.). Geoheritage: Assessment, Protection, and Management. Elsevier: Amsterdam, 2018. p. 13-25.

NICOD, J. Les karsts dinariques: paysages et problemes: Slovenie, Croatie, BosnieHerzegovine, Montenegro. Ljubljana: Zalozba ZRC, 2003. p. 87-112. 
PRATT, M.L. Humboldt e a reinvenção da América. Estudos Históricos, v.4, n.8, p.151-165, 1991.

REYNARD, E.; GIUSTI, C. The Landscape and the Cultural Value of Geoheritage. In: REYNARD, E., BRILHA, J. (Org.). Geoheritage: Assessment, Protection, and Management. Elsevier: Amsterdam, 2018. p. 147-166.

RICOTTA, L. Natureza, Ciência e Estética em Alexander von Humboldt. Rio de Janeiro: Mauad, 2003.

RIESCO JR., R. Enseñanzas y vigencia de Alexander Von Humboldt. Revista Geografía Norte Grande. Santiago, v.32, p.107-114, 2004.

RODAWAY, P. Yi-Fu Tuan. In: HUBBARD, P.; KITCHIN, R.; VALENTINE, G. (Eds.). Key thinkers on Space and Place. 4.ed. London: SAGE Publications Ltd., 2007. p. 306-310.

SCHEMES, E.F. A literatura de viagem como gênero literário e como fonte de pesquisa. In: SIMPÓSIO NACIONAL DE HISTÓRIA, 28, 2015. Anais... Santa Catarina: UFSC, 2015. p.1-13. Disponível em <http://www.snh2015.anpuh.org/resources/anais/39/ 1439245917_ARQUIVO_2.ARTIGOANPUH2015Elisa-Final.pdf > Acesso em: 20 mar. 2018.

TOBAR, L.R. La reescritura en los libros de viaje: las Cartas de Rusia de Juan Valera. In: TOBAR, L.R.; ELDUAYEN, P.A. (Coords.). Los libros de viaje: realidad vivida y género literario. Madrid: Akal, 2005. p.129-150.

TRAVASSOS, L.E.P. Considerações sobre o carste da região de Cordisburgo, Minas Gerais, Brasil. Belo Horizonte: Tradição Planalto, 2010.

TRAVASSOS, L.E.P. O carste e as cavernas nas obras de Alexander von Humboldt. Biblio 3W, v.18, n.1034, 2013.

TRAVASSOS, L.E.P.; KOHLER, H.C.; KRANJC, A. The 6th SINAGEO and the insertion of the Karst Geomorphology Thematic Session. Acta Carsologica, v.35, n.2, p.170-171, 2006.

TRAVASSOS, Luiz Eduardo Panisset. Espeleologia, Carstologia e a pesquisa científica. Revista Territorium Terram, v. 2, n. 4, p. 2-14, 2014.

TURLEY, G. Humboldt's Gift: a geographer in profile. Mercartor's World, v.6, n.6, p. 22$25,2001$.

VERNE, J. Mathias Sandorf. London: Sampson, Low, Marston, Searle \& Rivington,1889. v.1.

VERNE, J. Matias Sandorf. Rio de Janeiro: Edico: 1965.

VRIES-UITERWEERD, G. de. Maps from the Extraordinary Voyages, 2011. Disponível em: <http://verne.garmtdevries.nl/pics/maps/ms_full.jpg> Acesso em: 3 jun. 2018. 
YRIARTE, C. Les bords de l'Adriatique et le Monténégro. Venise, l'Istrie, le Quarnero, la Dalmatie, le Montenegro et la rive italienne. Paris: Hachette, 1878.

ZATTA, A.; ZULIANI, G.; COLUSSI, D. Parte Settentrionale dell' Istria. Parte meridionale dell Istria (Composite map). Venice: Presso Antonio Zatta, 1784. Disponível em: <https://www.davidrumsey.com> Acesso em 08 jun. 2018.

\section{Luiz Eduardo Panisset Travassos}

Bolsista de Produtividade em Pesquisa do CNPq. Doutor em Carstologia pela Universidade de Nova Gorica (Eslovênia). Professor adjunto do Departamento de Geografia da PUC Minas, onde também atua como docente permanente no Programa de Pós-Graduação em Geografia - Tratamento da Informação Espacial.

Avenida Dom José Gaspar 500, Coração Eucarístico, Belo Horizonte, Minas Gerais. CEP: 30535901

E-mail: luizepanisset@gmail.com

\section{Glaycon de Souza Andrade e Silva}

Graduando em Geografia da PUC Minas, onde também atua como estagiário do Projeto de Monitoramento Microclimático de grutas turísticas no estado de Minas Gerais no Programa de Pós-Graduação em Geografia - Tratamento da Informação Espacial.

Avenida Dom José Gaspar 500, Coração Eucarístico, Belo Horizonte, Minas Gerais. CEP: 30535901

E-mail: glaycongeografia@gmail.com

\section{Felipe de Ávila Chaves Borges}

Geógrafo, Mestre em Geografia e Bolsista CAPES. Doutorando em Geografia pelo Programa de Pós-Graduação em Geografia - Tratamento da Informação Espacial.

Avenida Dom José Gaspar 500, Coração Eucarístico, Belo Horizonte, Minas Gerais. CEP: 30535901

E-mail: felipeacborges@gmail.com 